\title{
Status of Litchi Cultivation in India
}

\author{
Ramesh Kumar Sahni ${ }^{1}$, Sweeti Kumari ${ }^{*}$, Manish Kumar ${ }^{1}$, \\ Manoj Kumar ${ }^{1}$ and Amrendra Kumar ${ }^{2}$
}

${ }^{1}$ ICAR-Central Institute of Agricultural Engineering, Bhopal, MP, (462 038), India

${ }^{2}$ ICAR-National Research Centre on Litchi, Muzzafarpur, Bihar (842 002), India

*Corresponding author

\section{A B S T R A C T}

Litchi is a popular subtropical fruit crop in India. It is the most delicious, juicy and nutritious fruit and mostly grown in Eastern India. Litchi cultivation is a source of livelihood security for a large population in litchi growing states as it provides

Keywords

Litchi, Litchi cultivation, Major variety, Export, India

\section{Article Info}

Accepted:

15 March 2020

Available Online:

10 April 2020 both on-farm and off-farm employment. The world scenario of litchi cultivation reveals that India is the second-largest producer of litchi after China with a total acreage over 93,300 ha and a yearly output of over 568,200 $t$ in 2016-17. However, with a productivity level of just $6.1 \mathrm{t} \mathrm{ha}^{-1}$, India lags behind several other litchi exporting countries. Litchi has particular climate and soil requirements, thus limiting its cultivation to a few states. Bihar is the leading litchi producing state followed by West Bengal, Jharkhand Assam and Chhattisgarh. Litchi varieties cultivated in India are highly diverse due to different climate and soil conditions. Major varieties are Shahi, China, Elaichi, Rose Scented, Bedana and Bombai. Litchi cultivation provides food, nutrition, employment opportunity, generate income, improve the socio-economic condition and poverty alleviation in rural areas of the different states of India. This paper discusses trends of litchi cultivation in major litchi growing states, commercially grown cultivars, their marketing and export potential in India.

\section{Introduction}

The Litchi (Litchi chinensis Sonn.) belongs to the Sapindaceae family and well known as the 'Queen of fruits'. Litchi was originated in near South China and North Vietnam in the year $1500 \mathrm{BC}$ but has now spread to different countries. Globally, South-East Asian countries including China, India, Vietnam and Thailand are the largest producers of litchi, but the fruit is also famous in Africa (South Africa and Madagascar), Australia, Indonesia, Spain, USA, Mexico, and Israel (Menzel, 2000; Rajwanshi et al., 2017). The fruit was introduced in India about 100 years later through Burma, from which it has spread to other parts of the tropical and subtropical areas of the country (Ghosh, 2000). Litchi crop is very specific to the climate requirement; probably because of this reason, 
its commercial cultivation is limited to few tropical and subtropical countries.

India is the $2^{\text {nd }}$ largest producer of litchi in the world after China. It is one of the most famous fruit crops and mostly cultivated in the Eastern part of the country. In India, 568,200 metric tons of litchis are produced annually from 93,300 hectares (Anonymous, 2018). The average productivity of litchi in the country is $6.1 \mathrm{t} \mathrm{ha}^{-1}$ in $2016-17$, which is much lower than the potential productivity of the crop. The main reasons for low productivity are poor fruit setting/ retention in hot, dry spring and biennial bearing due to poor nutrient management (Menzel and Simpson, 1990). Litchi being specific to the climatic requirement, it is restricted to only a few states with $66 \%$ of the total production of the country is recorded in Bihar, West Bengal and Jharkhand. Litchi crop mainly helps small and marginal farmers to get some additional income from their homesteads. Litchi cultivation is livelihood security for a large population in the litchi growing states as it offers both on-farm and off-farm employment opportunity. In the present study, the status of litchi cultivation in India has been reviewed.

\section{The trends in litchi cultivation}

In India, there has been a significant increase in area and production of litchi during the last three decades. The trend reveals that the area under litchi cultivation is expanding every year from 49,300 hectares in 1991-92 to 93,300 hectares in 2016-17 (Figure 1). Total production of litchi also boosted from 243,800 to 568,200 metric tons in the same time period. However, the productivity of litchi is stagnant about $6.1 \mathrm{t} \mathrm{ha}^{-1}$. The statistical analysis of time series data on area, production and productivity were done using SAS 9.3. The Augmented Dickey-Fuller Unit Root test was applied for detecting a trend in litchi cultivation using ARIMA procedure in
SAS 9.3, and the result is presented in Table 1.

The null hypothesis of this test was that the time series exhibits non-stationarity against the alternative of stationarity. Here, we had no evidence to reject the null hypothesis in case of area and production as p-value in these cases were $>0.05$ at lag 1 and 2 both. Thus, there was a significant trend in area and production of litchi. However, the p-value for productivity was $<0.05$, indicating that there was no trend in the productivity of litchi. Also, the same can be seen from the trends in the area, production and productivity in Figure 1.

\section{The nutritional value and products of litchi}

The food value of litchi fruit lies in its sugar content which changes based on the varieties. Depending upon its variety and climatic condition, litchi contains $60 \%$ juice, $19 \%$ seed, 13\% skin and $8 \%$ rag (Nath et al., 2016). Litchi is a very good source of minerals, several vitamins and healthy antioxidant which helps in protection from harmful free radicals. The nutritive values of litchi fruit per $100 \mathrm{gm}$ are shown in Table 2. Litchi is highly perishable fruit and several values added products are made from litchi. Litchi squash is a highly flavoured concentrated drink prepared from litchi pulp. Litchi nut is a dried litchi fruit, a very popular litchi product among Chinese. Several other products such as dehydrated litchi pulp, canned litchi, wine, juice, pickle, jelly, icecream and preserves are also prepared from litchi fruit.

\section{Major litchi growing states}

Litchi is commercially grown in the eastern part of India such as Bihar, West Bengal, Jharkhand, Uttarakhand, and Uttar Pradesh. The crop is also gaining popularity in Punjab, 
Himachal Pradesh, Jammu and Kashmir, Arunachal Pradesh, Tripura, Karnataka and Tamil Nadu because of its high profitability and better export potential (Pandey and Sharma, 1989; Cebeco, 2001). The major litchi growing states of the country are shown in Figure 2. Litchi could not freely spread like other fruit crops because of its specific climate and soil requirement. It requires warm subtropics climate, short dry, frost-free winters and long hot summers along with high rainfall and humidity (Mitra and Pathak, 2008). The soil should be a well-drained loamy soil, rich in organic matter and having 5 to $7 \mathrm{pH}$ range. The area, production, and productivity of litchi in the major litchi growing states from 2011-12 to 2013-14 are shown in Figure 3.

The percentage of area and production of litchi in different states from the year 2011-12 to 2013-14 is shown in Table 3. It is evident that Bihar is the leading state in litchi production $(40 \%)$ followed by West Bengal (16\%), Jharkhand (10\%), Assam (8.2\%), Chhattisgarh (6.4), Uttarakhand (5.2\%), Punjab (4.8\%), Orissa (3.5\%) and Tripura $(3.4 \%)$ in $2013-14$. Also, the state-wise value of the output of litchi is presented in Table 4.

The concentrated pockets of litchi in different states of India have been shown in Table 5. Bihar produces about $40 \%$ of total production and occupies about $37.4 \%$ of the area under litchi cultivation of India. In Bihar, litchi is mainly cultivated in Muzaffarpur, Vaishali, Darbhanga, Samastipur, Sitamarhi, West Champaran and East Champaran districts. Total litchi production in Bihar is about 234,200 tonnes from 31,480 hectare area under production with the productivity of 7.4 $\mathrm{t} \mathrm{ha}{ }^{-1}$, which is higher over the national productivity.

Litchi varieties cultivated in the country are highly variable due to different climatic and soil conditions (Singh and Babita, 2002). The state-wise popular variety of litchi is demonstrated in Table 6. Cv. Shahi is the most popular and best variety of Indian litchi because of its delicate aroma and flavour. $\mathrm{Cv}$. China is the second most popular variety of litchi. Litchi farmers are more interested in making new orchards of $\mathrm{cv}$. China, because it gives high productivity and more profitability. Cv. Shahi is the early variety, harvested between 15 May to 31 May, while cv. China is considered as the late variety. Other major varieties are Rose scented, Bombai, Elaichi, Dehradun, Bedana, Late large red, Late seedless, Calcuttia, Purbi etc.

The characteristics of the most common varieties of litchi cultivated in India are shown in Table 7. In West Bengal, Ghosh et al., (2000) found that cv. Bombai is the most common commercial variety, whereas cv. Bedana is superior in terms of quality with high pulp recovery and shrivelled seeds. $\mathrm{Cv}$. Early Large Red is the earliest variety and matures in the first week of May. In Tripura, Das (2013) studied the climatic condition of state with respect to the number of fruits per plants, time of maturity, bearing habit, and quality parameters of litchi crops. Cv. Shahi, cv.Swarna Roopa, cv. Muzaffarpur, cv.Late Bedana and cv. Bombai was found excellent in performance. However, cv. Shahi showed good performance in all the aspects such as flavour, taste, aroma and other quality parameters with excellent market demand.

\section{Arrival pattern in market and consumption}

India is gifted with unique ripening pattern of litchi, with harvesting period differs from state to state. The ripening of fruit commences from north-eastern part to the central part and then North to South India. The arrival time of litchi in the market of leading states of India is shown in Table 8. 
Litchi fruits are primarily consumed afresh. In litchi, the whole tree is normally harvested at one go and its shelf life is very short, i.e. 4-6 days at room temperature (Vijayanand et al., 2010). The fruits rapidly deteriorate its bright colouration and flavour within a few days; these make its transportation to distant market an uphill task. Several efforts to maintain its quality even for 7-10 days have not been successful leading to severe wastage and often causing a glut in the market and a large proportion of litchi fruits is rotting in India. However, in other countries, several other value-added products of litchi are popular. In China, dried nut (a dried litchi fruit) is very popular and exported to several countries on a large scale. Flavoured squash, dehydrated litchi pulp, canned litchi, juice, frozen fruits are some of the modes of preservation and consumption, which helps to avoid market glut and prevent rotting of litchi fruits. Frozen litchi fruits maintain its quality and flavour, if it is freshly harvested, rapidly cooled and kept at $-25{ }^{\circ} \mathrm{C}$ at which it remains in a good state for 1 year (Morevil, 1973). Litchi pulp can be stored for a longer period if it is heated to 85 ${ }^{\circ} \mathrm{C}$ and added with $500 \mathrm{ppm} \mathrm{SO}_{2}$ and $1 \%$ citric acid. The fruit can be stored for 6 months at $25-35{ }^{\circ} \mathrm{C}$ and 1 year at $4-5{ }^{\circ} \mathrm{C}$ (Sethi, 1985).

\section{Litchi markets of the country}

Litchi fruit is a temperature-sensitive; its access to the distant market is constrained due to unavailability of transportation with cool chain facilities. It is essential for the product to reach distant market locations within 24-36 hours after harvesting to retain its desired flavour and colour at ambient temperature. The current litchi supply chains from the production location to the final consumers outside the state market often take more than 24-36 hours. Hence, goods refrigerated trucks and cold storage chain facilities are necessary for targeting distant markets while fruit requires processing to increase its shelf life for export markets. Litchi markets can be broadly classified into three different categories: domestic, national and export market. According to the survey estimates in Bihar, about $80 \%$ of the total litchi produced in the state is being exported to the other states out of which the major markets are Delhi, Varanasi, Lucknow, Mumbai, Kanpur, Kolkata Chandigarh and Bangalore (Anonymous, 2010). The price of litchi (Rs/ Qtl.) and quantity of litchi arrival (MT) in the major markets are shown in Table 9. The average wholesale price and the annual arrival of litchi in the major market of litchi are shown in Figure 4. It indicates that Delhi as the highest-selling market, followed by Patna, Kolkata and Lucknow.

\section{Exports potential}

Currently, Indian litchi is exported mainly to UAE, Nepal, Thailand, France, Saudi Arabia, Canada and several other countries. The Agricultural and Processed Food Products Export Development Authority (APEDA) and the National Agency for Export Development (NAFED) are the major export promoters of litchi fruits in the country (APEDA, 2017). The demand of litchi fruits from the USA, Arab nations, Europe and different other countries are increasing day by day. However, minimal effort has been made to capture the litchi world market from China, the leading exporter of litchi. The quantity and value for the export of litchi to different countries are shown in Table 10.

In conclusion, litchi is a climate and soil specific fruit plant, introduced in India in the $18^{\text {th }}$ Century has well adapted to the climate of Eastern India and a very good source of minerals, vitamins and healthy antioxidant. Due to its increasing demand and profitability, the area under cultivation and production has increased manifold in the last 
three decades. However, the lower productivity, poor nutrient management, biennial bearing of fruits, low shelf life and lack of cold chain transport and cold storage facility are the major constraints with litchi cultivation among all varieties of litchi in India, $\mathrm{Cv}$. Shahi is the most popular and best variety in all aspects such as flavour, taste, aroma with excellent market demand. Unique ripening pattern in a different part of the country makes litchi available for longer duration in the Indian market. APEDA and NAFED are promoting the export of litchi to the other country, but more effort need to be made to capture some part of the litchi world market.

Table.1 Detection of trend in area, production and productivity of litchi

\begin{tabular}{|l|c|c|}
\hline \multirow{2}{*}{} & \multicolumn{2}{|c|}{$p$ value } \\
\hline Area & Lag 1 & Lag 2 \\
\hline Production & 0.0877 & 0.7772 \\
\hline Productivity & 0.0982 & 0.1723 \\
\hline
\end{tabular}

Table.2 Nutritive value of aril of litchi fruit per $100 \mathrm{~g}$

\begin{tabular}{|l|c|c|}
\hline \multicolumn{1}{|c|}{ Constituents } & Fresh aril (per $\mathbf{1 0 0}$ g) & Dried aril \\
\hline Calories & $63-64$ & 277 \\
\hline Moisture & $81-85 \%$ & $17.99-22.3 \%$ \\
\hline Protein & $0.68-1.0 \mathrm{~g}$ & $2.9-3.8 \mathrm{~g}$ \\
\hline Fat & $0.30-.58 \mathrm{~g}$ & $0.2-1.2 \mathrm{~g}$ \\
\hline Carbohydrate & $13.31-16.40 \mathrm{~g}$ & $70.7-77.5 \mathrm{~g}$ \\
\hline Fibre & $0.23-0.40 \mathrm{~g}$ & $1.4 \mathrm{~g}$ \\
\hline Ash & $0.37-0.50 \mathrm{~g}$ & $1.5-2 \mathrm{~g}$ \\
\hline Calcium & $8-10 \mathrm{mg}$ & $33 \mathrm{mg}$ \\
\hline Phosphorus & $30-42 \mathrm{mg}$ & - \\
\hline Iron & $0.40 \mathrm{mg}$ & $1.7 \mathrm{mg}$ \\
\hline Sodium & $3 \mathrm{mg}$ & $3 \mathrm{mg}$ \\
\hline Potassium & $170 \mathrm{mg}$ & $1100 \mathrm{mg}$ \\
\hline Thiamine & $28 \mathrm{mg}$ & - \\
\hline Nicotinic acid & $0.40 \mathrm{mg}$ & - \\
\hline Riboflavin & $0.05 \mathrm{mg}$ & 0.05 \\
\hline TSS ( ${ }^{0}$ Brix $)$ & $18-22$ & $\mathrm{NA}$ \\
\hline Ascorbic acid & $24-60 \mathrm{mg}$ & $42 \mathrm{mg}$ \\
\hline
\end{tabular}

Source: Singh et al., (2012). 
Table.3 Percentage of area and production of litchi in different states

\begin{tabular}{|l|c|c|c|c|c|c|}
\hline State & \multicolumn{2}{|c|}{$\mathbf{2 0 1 1 - 1 2}$} & \multicolumn{2}{c|}{$\mathbf{2 0 1 2 - 1 3}$} & \multicolumn{2}{c|}{ 2013-14 } \\
\hline & \% Area & \% Production & \% Area & \% Production & \% Area & \% Production \\
\hline Bihar & 38.7 & 43.9 & 37.8 & 44.2 & 37.4 & 40 \\
\hline West Bengal & 11.1 & 15.9 & 11.1 & 15.5 & 11 & 16 \\
\hline Jharkhand & 6 & 10.7 & 6.4 & 10 & 6.3 & 10 \\
\hline Assam & 6.6 & 7.7 & 6.8 & 8.6 & 6.4 & 8.2 \\
\hline Chhattisgarh & 5.6 & 5 & 6 & 5.3 & 6.4 & 6.4 \\
\hline Uttarakhand & 11.8 & 3.5 & 11.5 & 3.3 & 11.2 & 5.2 \\
\hline Punjab & 2.1 & 4.6 & 2.1 & 4.6 & 2.2 & 4.8 \\
\hline Odisha & 5.6 & 3.7 & 5.4 & 3.5 & 5.3 & 3.5 \\
\hline Tripura & 4 & 3.1 & 4.2 & 3.1 & 4.6 & 3.4 \\
\hline Others & 8.6 & 1.9 & 8.7 & 1.9 & 9.2 & 2.4 \\
\hline
\end{tabular}

Table.4 State wise value of output of litchi in Rs. Lakhs

\begin{tabular}{|l|l|c|c|c|c|c|c|}
\hline & & \multicolumn{3}{|c|}{ (AT CURENT PRICES) } & \multicolumn{3}{c|}{ (AT 2011-12 PRICES) } \\
\hline S. No. & State/U.Ts & $2011-12$ & $2012-13$ & $2013-14$ & $2011-12$ & $2012-13$ & $2013-14$ \\
\hline 1 & Arunachal Pradesh & 427 & 503 & 603 & 427 & 427 & 427 \\
\hline 2 & Assam & 11544 & 15097 & 14744 & 11544 & 13808 & 13374 \\
\hline 3 & Bihar & 84745 & 92817 & 84771 & 84745 & 91925 & 83956 \\
\hline 4 & Chhattisgarh & 7225 & 10526 & 11731 & 7225 & 8235 & 10032 \\
\hline 5 & Haryana & 266 & 872 & 1646 & 266 & 727 & 1219 \\
\hline 6 & Himachal Pradesh & 1227 & 1600 & 1794 & 1227 & 1252 & 1339 \\
\hline 7 & Jammu \& Kashmir & 685 & 243 & 244 & 685 & 190 & 208 \\
\hline 8 & Jharkhand & 20613 & 21077 & 21079 & 20613 & 20874 & 20876 \\
\hline 9 & Mizoram & 326 & 340 & 381 & 326 & 326 & 332 \\
\hline 10 & Nagaland & 38 & 480 & 837 & 38 & 450 & 725 \\
\hline 11 & Odisha & 10667 & 13744 & 13386 & 10667 & 10752 & 10784 \\
\hline 12 & Punjab & 9655 & 10451 & 11179 & 9655 & 10451 & 11036 \\
\hline 13 & Tripura & 4076 & 4839 & 6429 & 4076 & 4412 & 4955 \\
\hline 14 & Uttar Pradesh & 493 & 567 & 763 & 493 & 559 & 696 \\
\hline 15 & Uttarakhand & 9895 & 11607 & 15991 & 9895 & 9978 & 15991 \\
\hline 16 & West Bengal & 61836 & 67734 & 57031 & 61836 & 65243 & 68070 \\
\hline 17 & Chandigarh & 23 & 29 & 0 & 23 & 23 & 0 \\
\hline & Total & 223739 & 252526 & 242609 & 223739 & 239633 & 244020 \\
\hline Source: Horticultural Statistics at a Glance 2017 & & & & & \\
\hline
\end{tabular}


Table.5 Major litchi producing belts in India

\begin{tabular}{|c|c|}
\hline States & Districts \\
\hline Assam & $\begin{array}{l}\text { Dibrugarh, Goalpara, Sonitpur, Lakhimpur, Jorhat, Golaghat, Kamrup, Nalbari, } \\
\text { Barpeta, Bongaigaon, Nagaon }\end{array}$ \\
\hline Bihar & $\begin{array}{l}\text { Muzaffarpur, Vaishali, East Champaran, West Champaran, Sitamarhi, Sheohar, } \\
\text { Samastipur, Bhagalpur }\end{array}$ \\
\hline Chhattisgarh & Korba, Raigarh, Surguja, Jashpur, Surajpur, Balrampur, Koriya, Narayanpur \\
\hline Himachal Pradesh & Kangra (Palampur, Panchrukhi, Dharmshala), Sirmour (Paonta Sahib, Dhaula kuan) \\
\hline Jammu \& Kashmir & Jammu, Samba, Kathua, Udhampur, Reasi \\
\hline Jharkhand & Ramgarh, Ranchi, Hazaribagh, Gumla \\
\hline Madhya Pradesh & Shahdol, Sidhi, Madla, Dindori \\
\hline Manipur & Imphal West, Bishnupur, Imphal East, Thoubal, Churachandpur, Chandel \\
\hline Meghalaya & East Khasi Hills, Ri-bhoi, Garo Hills \\
\hline Nagaland & $\begin{array}{l}\text { Kohima, Wokha, Mokokchung, Tuensang, Zunheboto, Phek, Kiphire, Longleng, } \\
\text { Mon, Dimapur, Peren }\end{array}$ \\
\hline Odisha & Sambalpur, Debagarh (Deogarh), Sundergarh, Rayagada, Koraput \\
\hline Punjab & Gurdaspur, Hoshiarpur, Ropar \\
\hline Sikkim & $\begin{array}{l}\text { North Sikkim (Phidang), East Sikkim (Majhitar, Bhasmey, Rorathang, Makha, } \\
\text { Ralep, Mulukey), South Sikkim (Kitam, Pakzor, Chalamthamthang, Kichudumra), } \\
\text { West Sikkim (Sagbari, Kamling) }\end{array}$ \\
\hline Tamil Nadu & Tiruvarur, Vellore, Vilupuram \\
\hline Uttar Pradesh & Saharanpur, Muzaffarnagar, Kushinagar \\
\hline Uttarakhand & Nainital, Udham Singh Nagar, Haridwar, Dehradun, Almora \\
\hline West Bengal & Malda, Murshidabad, 24 Parganas (North \& South), Uttar Dinajpore, Cooch Behar \\
\hline
\end{tabular}


Table.6 Major litchi producing states and variety cultivated

\begin{tabular}{|c|c|}
\hline States & Recommended cultivars \\
\hline Bihar & Shahi, China, Rose Scented, Bedana, Late seedless, late large red, purbi \\
\hline Jharkhand & Shahi, China, Rose Scented, Bedana, Late seedless, Late large red, purbi \\
\hline Orissa & Late large red \\
\hline Assam & Shahi, China, Bombai, Deshi \\
\hline Sikkim & Shahi \\
\hline Manipur & Late large red \\
\hline Meghalaya & Late large red \\
\hline Nagaland & China, Late large red \\
\hline West Bengal & Bombai, Bedana, Ellaichi, China, Late large Red, Purbi, Early large Red \\
\hline Chhattisgarh & Shahi, Late Large Red \\
\hline Madhya Pradesh & Shahi, Late Large Red \\
\hline Uttar Pradesh & Shahi, China, Rose Scented, Bedana, Dehradun, Calcuttia \\
\hline Uttarakhand & Shahi, China, Bedana, Rose Scented, Dehradun, Late seedless \\
\hline Punjab & Rose Scented, Dehradun, Late Seedless \\
\hline Himachal Pradesh & Rose Scented, Dehradun Calcuttia \\
\hline Jammu \& Kashmir & Rose Scented, Dehradun, Calcuttia \\
\hline Tamil Nadu & Rose Scented, Dehradun, Late Seedless, Late Large Red, Calcuttia \\
\hline Tripura & Shahi, Mazaffarpur, Swarna Roopa, Bombai, Late Bedana \\
\hline
\end{tabular}


Table.7 Characteristics of commercially grown litchi cultivars in eastern India

\begin{tabular}{|l|l|}
\hline \multicolumn{1}{|c|}{ Variety } & \multicolumn{1}{c|}{ Characteristics } \\
\hline Shahi & $\begin{array}{l}\text { Early maturing, regular bearer, heavy yielding, fruits are globous- heart orobtuse in shape. } \\
\text { The colour is rose madder and fuchsia purple background with red tubercles at ripening. } \\
\text { weight: } 20-25 \mathrm{~g}, \text { T.S.S.: } 19-22^{\circ} \text { brix }\end{array}$ \\
\hline China & $\begin{array}{l}\text { Late maturing, oblong to conical shaped fruit with dark pink colour skin, weight: } 20-25 \mathrm{~g}, \\
\text { aril sweet juicy aroma with excellent quality, heavy yielder, resistant to fruit cracking and } \\
\text { sun burning }\end{array}$ \\
\hline Early Bedana & $\begin{array}{l}\text { Oval or heart shaped, colour: uranium green with carminered tubercles at maturity, fruit } \\
\text { size: medium, weight: } 15-18 \mathrm{~g} . \text { with T.S.S.: } 17.2-19.8^{\circ} \text { brix }\end{array}$ \\
\hline Late Bedana & $\begin{array}{l}\text { Conical in shape, colour: vermilion to carmine with darkblackish-brown tubercles at } \\
\text { maturity and the fruit size is medium, withT.S.S. of } 18-20^{\circ} \text { brix }\end{array}$ \\
\hline Bombai & $\begin{array}{l}\text { Fruits are obliquely heart shaped. The colour is carmine red and the fruitsize is large, and } \\
\text { weighs } 15-20 \mathrm{~g} . \text { with T.S.S. of } 17^{\circ} \text { brix }\end{array}$ \\
\hline Kasba & $\begin{array}{l}\text { Mid-late maturing, shape }: \text { oval to round with deep red skin colour, weight } 22-25 \mathrm{~g}, \text { high } \\
\text { yielder, resistant to fruit cracking and sun burning }\end{array}$ \\
\hline Rose Scented & $\begin{array}{l}\text { Mid-early maturing, crimson red coloured fruit, aril with rosy aroma, excellent quality, } \\
\text { regular bearer, heavy yielder }\end{array}$ \\
\hline Fehradun & $\begin{array}{l}\text { Fruits are obliquely heart to conical shape, bright rose pink coloured skin with attractive } \\
\text { fruit weighing about } 18-20 \mathrm{~g}, \text { high yielder }\end{array}$ \\
\hline
\end{tabular}

Table.8 The arrival pattern of litchi in leading states

\begin{tabular}{|r|l|l|}
\hline S. No. & States & Season of availability \\
\hline 1 & Tripura & $15^{\text {th }}$ April to end of April \\
\hline 2 & Assam & $3^{\text {rd }}$ week of May \\
\hline 3 & West Bengal & $1^{\text {st }}$ May to $3^{\text {rd }}$ week of May \\
\hline 4 & Bihar & $3^{\text {rd }}$ week of May to $2^{\text {nd }}$ week of June \\
\hline 5 & Jharkhand & $3^{\text {rd }}$ week of May to $2^{\text {nd }}$ week of June \\
\hline 6 & Uttarakhand & $2^{\text {nd }}$ week of June to $4^{\text {th }}$ week of June \\
\hline 7 & Punjab & $3^{\text {rd }}$ week of June to last week of June \\
\hline 8 & Himachal Pradesh & $3^{\text {rd }}$ week of June to last week of June \\
\hline 9 & Tamil Nadu & $15^{\text {th }}$ December to $15^{\text {th }}$ January \\
\hline 10 & Karnataka & $15^{\text {th }}$ December to $15^{\text {th }}$ January \\
\hline 11 & Kerala & $15^{\text {th }}$ December to $15^{\text {th }}$ January \\
\hline
\end{tabular}


Table.9 Monthly average wholesale price (in Rs/ Qtl.) \& total arrival of litchi in 2014

\begin{tabular}{|l|c|c|c|c|c|c|c|c|c|c|c|c|}
\hline Market & \multicolumn{2}{|c}{ May } & \multicolumn{2}{|c|}{ June } & \multicolumn{2}{c|}{ July } & \multicolumn{2}{c|}{ August } & \multicolumn{2}{c|}{ November } & \multicolumn{2}{c|}{ Annual } \\
\hline & Price & Arrival & Price & Arrival & Price & Arrival & Price & Arrival & Price & Arrival & Price & Arrival \\
\hline Amritsar & 0 & 0 & 4646 & 291 & 0 & 0 & 0 & 0 & 0 & 0 & 4646 & 291 \\
\hline Bhubaneshwar & 10417 & 17 & 9722 & 21 & 0 & 0 & 0 & 0 & 0 & 0 & 10070 & 38 \\
\hline Chandigarh & 4605 & 165 & 4910 & 446 & 5131 & 203 & 0 & 0 & 0 & 0 & 4882 & 814 \\
\hline Dehradun & 0 & 0 & 4956 & 265 & 6821 & 11 & 0 & 0 & 0 & 0 & 5889 & 276 \\
\hline Delhi & 8542 & 1811 & 7475 & 5919 & 7748 & 1273 & 0 & 0 & 0 & 0 & 7922 & 9003 \\
\hline Gangatok & 0 & 0 & 7120 & 32 & 0 & 0 & 0 & 0 & 0 & 0 & 7120 & 32 \\
\hline Guwahati & 3160 & 259 & 5062 & 283 & 0 & 0 & 0 & 0 & 0 & 0 & 4111 & 542 \\
\hline Jaipur & 7578 & 316 & 6241 & 376 & 0 & 0 & 0 & 0 & 0 & 0 & 6910 & 692 \\
\hline Jammu & 0 & 0 & 7967 & 206 & 6381 & 556 & 6000 & 7 & 0 & 0 & 6783 & 769 \\
\hline Kolkata & 5443 & 540 & 4411 & 762 & 0 & 0 & 0 & 0 & 0 & 0 & 4927 & 1302 \\
\hline Lucknow & 5739 & 302 & 4536 & 974 & 0 & 0 & 0 & 0 & 0 & 0 & 5138 & 1276 \\
\hline Mumbai & 0 & 0 & 0 & 0 & 0 & 0 & 0 & 0 & 1350 & 160 & 1350 & 160 \\
\hline Patna & 3325 & 202 & 4112 & 1769 & 0 & 0 & 0 & 0 & 0 & 0 & 3719 & 1971 \\
\hline Raipur & 8400 & 271 & 7875 & 100 & 0 & 0 & 0 & 0 & 0 & 0 & 8138 & 371 \\
\hline Ranchi & 4460 & 136 & 3925 & 235 & 0 & 0 & 0 & 0 & 0 & 0 & 4193 & 371 \\
\hline Shimla & 0 & 0 & 6092 & 38 & 7275 & 45 & 0 & 0 & 0 & 0 & 6684 & 83 \\
\hline
\end{tabular}

Table.10 Export of Litchi from India - Country Wise

\begin{tabular}{|l|c|c|c|c|c|c|}
\hline \multirow{2}{*}{ Country } & \multicolumn{2}{|c|}{$2014-15$} & \multicolumn{2}{c|}{$2015-16$} & \multicolumn{2}{c|}{$2016-17$} \\
\cline { 2 - 7 } & Qty (MT) & Rs. Lacs & $\begin{array}{c}\text { Qty } \\
\text { (MT) }\end{array}$ & Rs. Lacs & Qty (MT) & Rs. Lacs \\
\hline United Arab Emirates & 0.03 & 0.01 & 0.03 & 0.02 & 20.37 & 52.68 \\
\hline Nepal & 44.6 & 17.73 & 9.4 & 3.84 & 53.96 & 30.77 \\
\hline Thailand & 0 & 0 & 0 & 0 & 50 & 20.93 \\
\hline France & 0 & 0 & 0 & 0 & 0.46 & 1.2 \\
\hline Kuwait & 0.09 & 0.09 & 0.12 & 0.3 & 0.33 & 0.46 \\
\hline Canada & 0 & 0 & 0 & 0 & 0.2 & 0.18 \\
\hline Qatar & 0 & 0 & 0 & 0 & 0.05 & 0.06 \\
\hline Bangladesh & 915 & 163.8 & 0 & 0 & 0 & 0 \\
\hline United Kingdom & 0.08 & 0.2 & 0 & 0 & 0 & 0 \\
\hline Bahrain & 0 & 0 & 0.2 & 0.16 & 0 & 0 \\
\hline Others & 1.63 & 33.35 & 0.12 & 0.05 & 0 & 0 \\
\hline Total & 961.43 & 215.18 & 9.87 & 4.37 & 125.37 & 106.28 \\
\hline Source: Horticultural Statistics at a Glance 2017 & & & & & \\
\hline
\end{tabular}


Figure.1 Trend of area, production and productivity of litchi in India

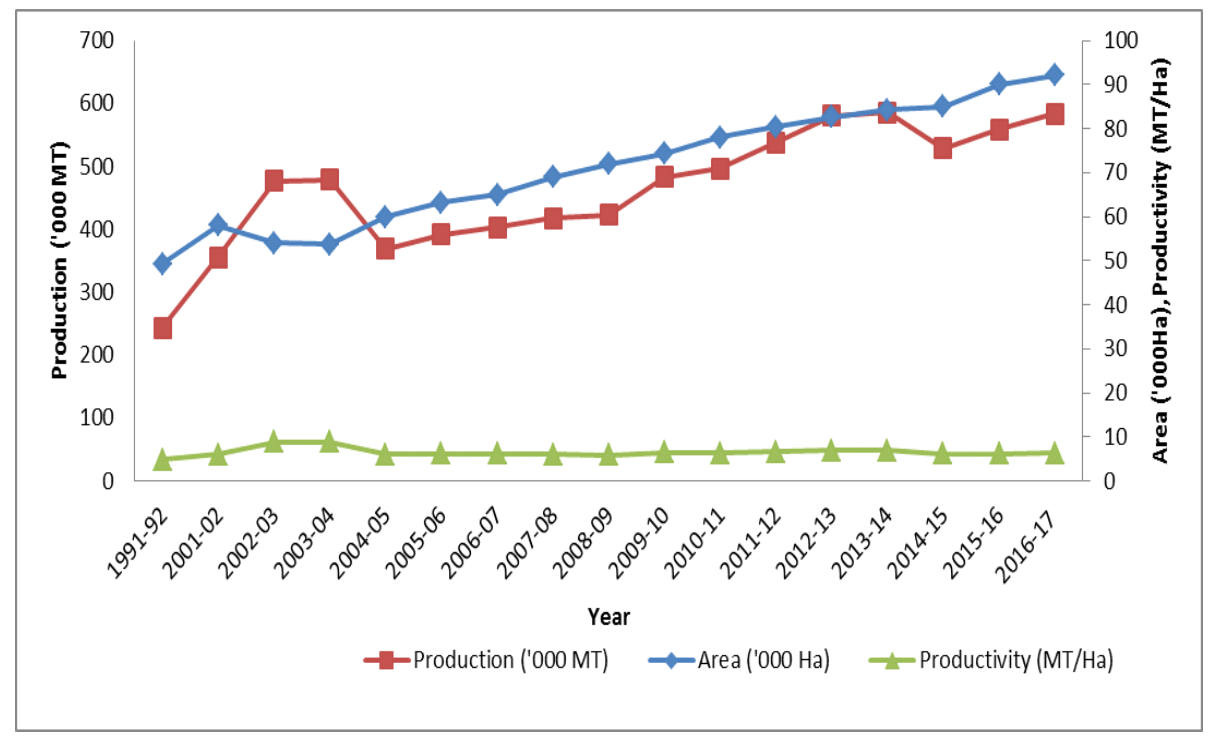

Figure.2 Major litchi producing states of India

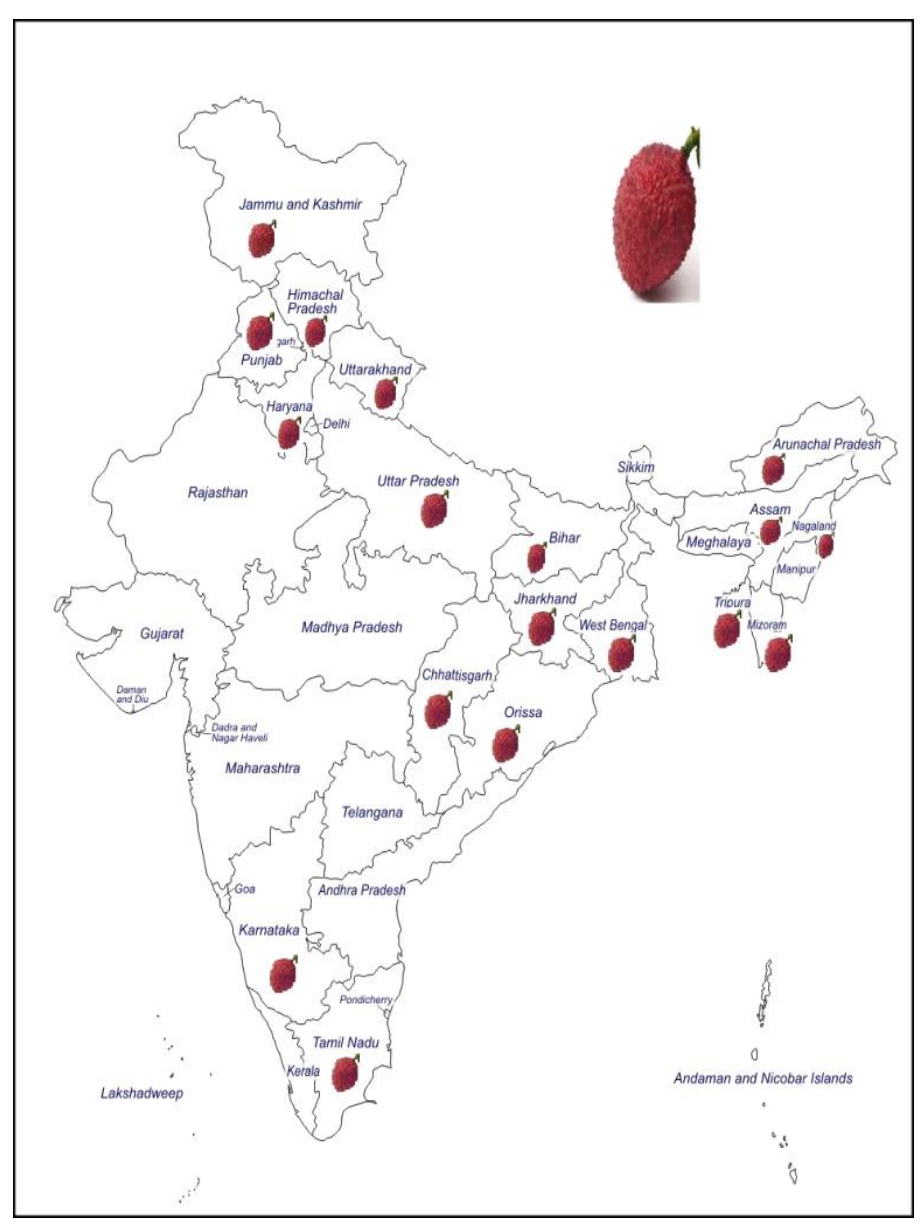


Figure.3 State wise (a) area (b) production and (c) productivity of litchi

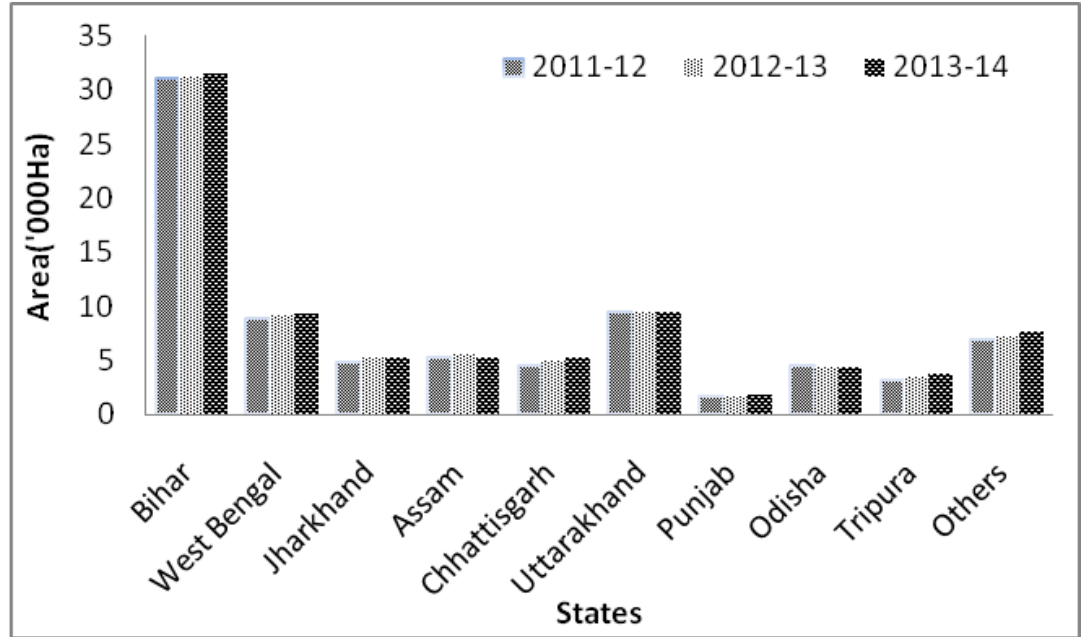

(a)

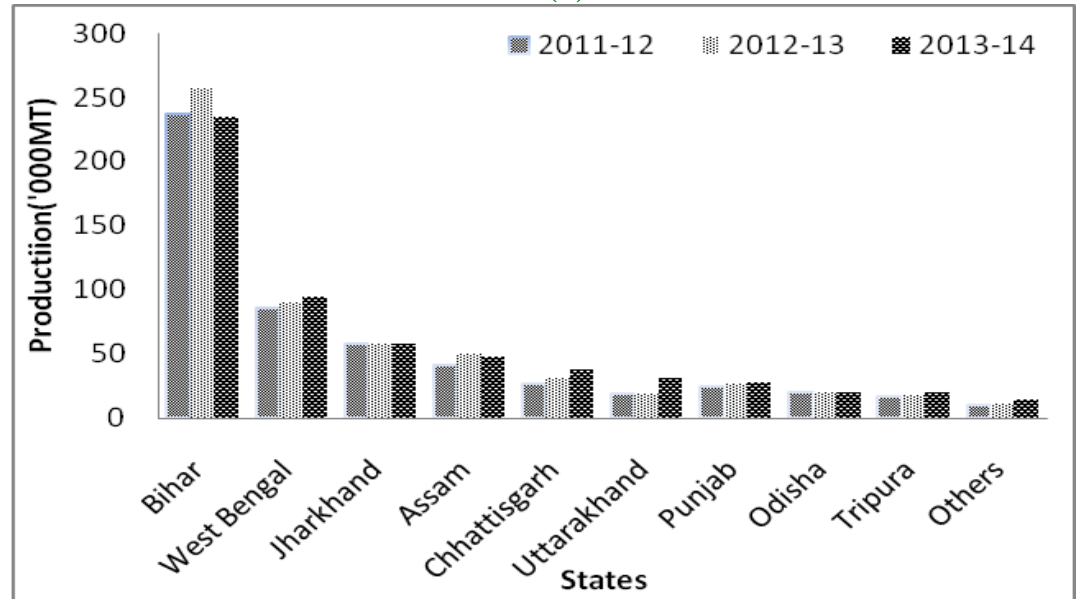

(b)

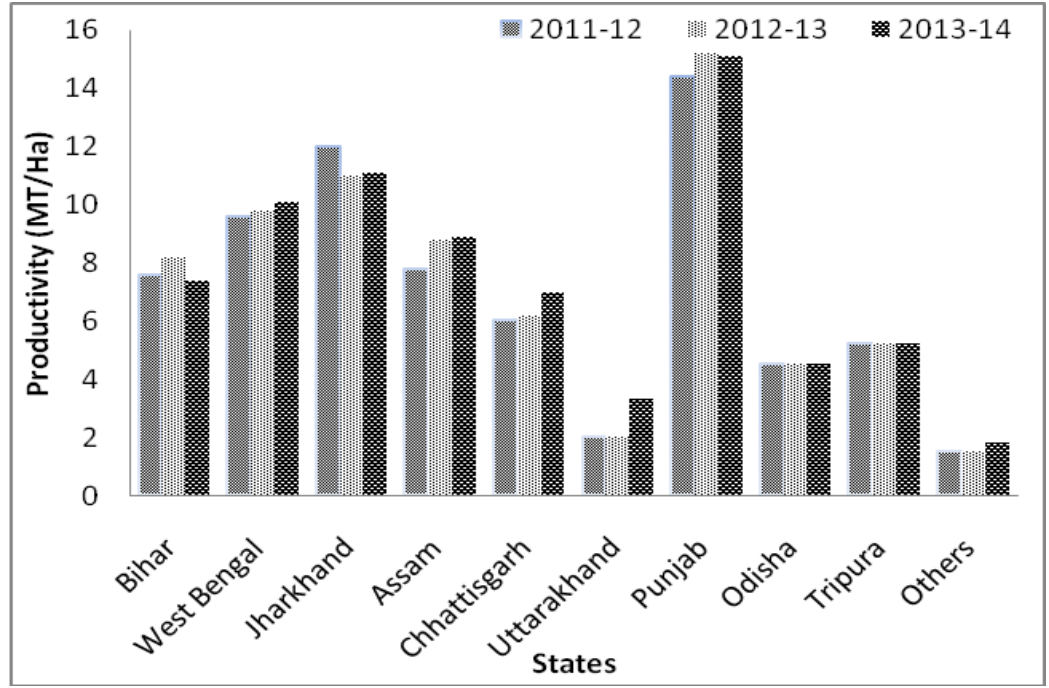

(c) 
Figure.4 Average wholesale price and annual arrival of litchi in major market of litchi

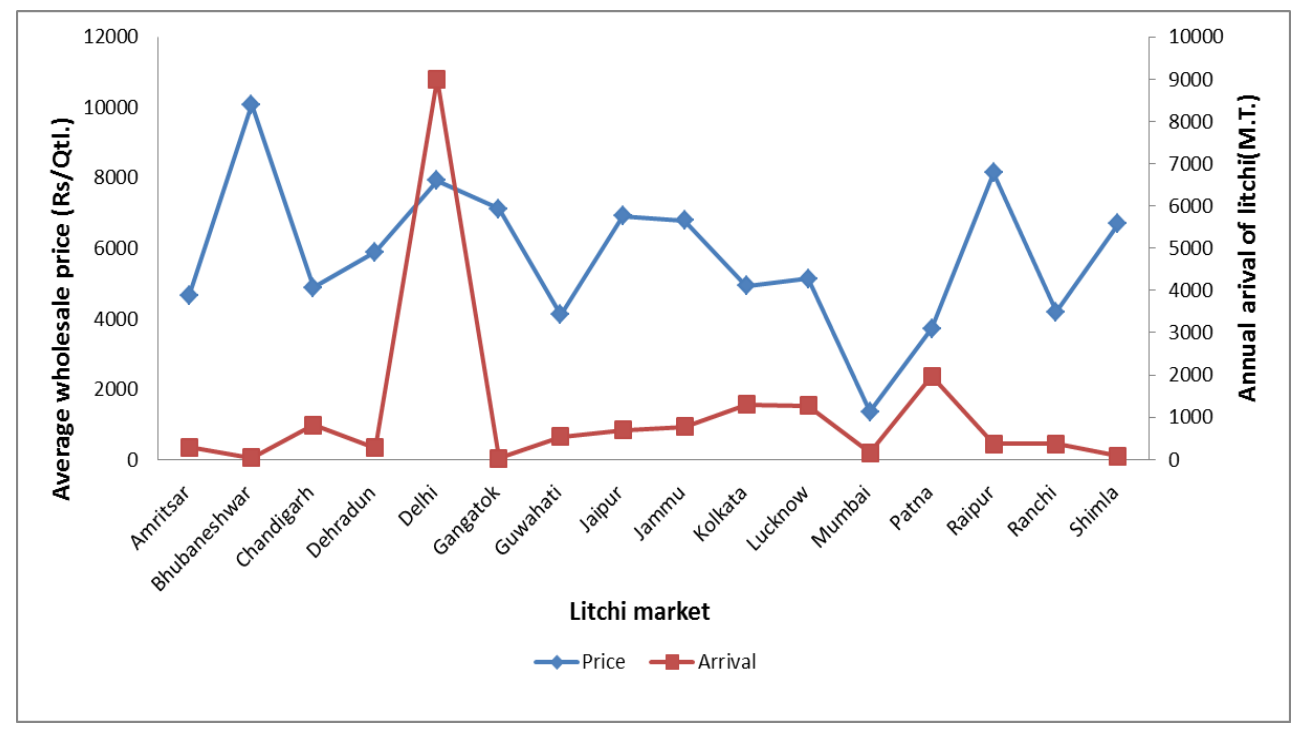

\section{References}

Anonymous, 2010. Litchi resource mapping, Bihar. IL\&FS Clusters Development Initiative Limited, New Delhi.

Anonymous, 2017. Horticultural Statistics at a Glance 2017. Horticulture Statistics Division, Department of Agriculture, Cooperation \& Farmers Welfare, Ministry of Agriculture \& Farmers Welfare, New Delhi.

Anonymous, 2018. Horticultural Statistics at a Glance 2018. Horticulture Statistics Division, Department of Agriculture, Cooperation \& Farmers Welfare, Ministry of Agriculture \& Farmers Welfare, New Delhi.

APEDA, 2017. Annual Report. APEDA, New Delhi.

Cebeco, 2001. Project report for setting up agriexport zone for litchi in Ramnagar, Uttaranchal, Cebeco India Pvt. Ltd., New Delhi.

Das, S.C., 2013. Studies of litchi cultivation and evaluation of different varieties and hybrids in Tripura. Asian J. Hort., 8(2): 520-525.

Ghosh, B., Mitra, S.K. and Sanyal, D., 2000. Litchi cultivars of west Bengal, India. ${ }^{\text {st }}$
International Symposium on Litchi and Longan 558. 107-113.

Ghosh, S.P., 2000. World trade in litchi: past, present and future. $1^{\text {st }}$ International Symposium on Litchi and Longan 558, 23-30.

Menzel, C., 2000. The physiology of growth and cropping in lychee. In $I^{s t}$ International Symposium on Litchi and Longan. 558. 175-184.

Menzel, C.M. and Simpson, D.R., 1990. Performance and improvement of lychee cultivars: a review. Fruit Varieties Journal, 44(4), 197-215.

Mitra, S.K. and Pathak, P.K., 2008. Litchi production in the Asia-Pacific region. III $^{\text {rd }}$ International Symposium on Longan, Lychee, and other Fruit Trees in Sapindaceae Family 863. 29-36.

Morevil, C., 1973. Some observation and trials on the litchi fruits. 28, 637-640.

Nath, V., Kumar, G., Pandey, S.D. and Gupta, A.K., 2016. Status of litchi in India. $V^{\text {th }}$ International Symposium on Lychee, Longan and Other Sapindaceae Fruits. 1211, 153-160.

Pandey, R.M. and Sharma, H.C., 1989. The litchi. Indian Society of Soil Science; New Delhi. 
Rajwanshi, R., Kumar, M. and Lal, B., 2017. Pre-and postharvest management practices for Litchi production in India. In Lychee Disease Management. Springer. 45-66.

Sethi, V., 1985. A simple and low cost preservation of litchi juice. Indian Food Packer 39(4):42-48

Singh, G., Nath, V., Pandey, S.D., Ray P.K. and Singh H.S., 2012. The Litchi, FAO, New Delhi, India
Singh, H.P. and Babita, S., 2002. Lychee production in India. Lychee Production in the Asian-Pacific Region. Food and Agriculture Organization of the United Nations, Bangkok. 55-67.

Vijayanand, P., Kulkarni, S.G. and Prathibha, G.V., 2010. Effect of pectinase treatment and concentration of litchi juice on quality characteristics of litchi juice. Journal of food science and technology, 47(2): 235-239.

\section{How to cite this article:}

Ramesh Kumar Sahni, Sweeti Kumari, Manish Kumar, Manoj Kumar and Amrendra Kumar. 2020. Status of Litchi Cultivation in India. Int.J.Curr.Microbiol.App.Sci. 9(04): 1827-1840.

doi: https://doi.org/10.20546/ijcmas.2020.904.214 